\title{
Effects of Digital Citizenship on EFL Students' Success in Writing
}

\author{
Asmaa F. Alazemi, Imad T. Sa'di and Dina AH Al-Jamal \\ Yarmouk Ubiversity, \\ Irbid, Jordan
}

\begin{abstract}
This study aimed at infusing digital citizenship elements in language classes and check if the exposure to such elements in international English content, in an interactive online mode, affect tenth grade writing performance. To achieve the aim of the study, an instructional digital citizenship program entailing Ribble, Bailey, and Ross's (2004) elements was designed in light of the witing activities in Over to You textbook. A quasi-experimental research design was followed by the means of a pre-post writing test administered on 40 students selected from a basic school in Kuwait as two intact sections (N. 20 students each) and then assigned randomly into an experimental group and a control. The study reported a statistically significant impact on participants' writing performance.
\end{abstract}

Keywords: Digital citizenship, instructional program, Yarmouk university, EFL writing.

\section{Introduction}

Education informs and empowers societies. It creates the social behaviors of individuals. By the means of education, proper molding of social behaviors is created such as interacting in the face-to-face world or in the virtual world where values that connect diverse sectors of society are demonstrated. Here, learners do not only need core cognitive competencies but also they need virtual platforms competencies (i.e. non-cognitive competencies) (Werbner, 2000; Casltes \& Alastai, 2000; Richardson \& Milovidov, 2019).

In recent times, technology is more than welcomed by language teachers. Particularly, in Kuwait, education is imperative to advance the superiority of life, increases literacy and sensibility to take gains that were not felt before, and shapes individual's social behavior. To stay internationally competitive and mature responsible citizens, EFL teachers can intertwine the competencies of this century during the course of the English language classes by enhancing their students' blogging, commenting and discussion online skills. 
Citizenship, to Dower (2003) and Ibrahim (2005), is all about growing individual's commitment towards society by reflecting, demonstrating and sharing beliefs, responsibilities, understanding, rights and thoughtfulness necessary for being active participants in society. Education is charged not just with infusing knowledge, but teaching societal skills as well (Crick, 2007). It is responsible for enhancing individual's learning of norms of societal skills and how to cope with others (Ross, 2007).As learners log in different social sites and converse with others, digital citizenship needs to be attended seriously. Initially phrases such as "Ignore untrusted forums," "don't blog", "never share", "Don't talk to foreigners, and "are very common when talking with young learners. Appropriate practices for online exchange are vital as in the face-to-face world; so young learners may need to take part in blogs, forums, and various types of virtual platforms. Social media tools and applications (e.g. Facebook, LinkedIn, Twitter, Forums...etc.) give individuals prospects to network and talk (Anderson, 2001; Anderson, 2015).

On top of their teaching everyday jobs, language teachers need to inform their students about matters that are likely touch their societies (Brown, 1991; Cummins, 1981). Infusing electronic citizenship in students' writings, accordingly, encompass language teachers' attention to up-to-date themes associated to numerous societal ethos and beliefs (Brookfield,1995).

Effective learning involves interaction and partnership (Vygoysky, 1978). In this context, Medges (1998) stated that language content together with language competency should be insured concurrently; as effective learning takes place as a result of an integration of the content (topic/ theme) with the content carrier. Byram (2008) shared a model that involves an expansion of the role of the teacher to account not only for learners' language abilities; but further to consider their 'general' abilities in out-school activities. Let's say, EFL teachers may invite their students to write on a current citizenship societal issue while simultaneously checking lexis, structure, genre and style.

\section{Context}

After the so-called Arab spring, Kuwait had paid excessive prominence to active citizens, especially as ISI and Sheeah were on the outstretched. The idea of society unity and participation has grown merit in mass media. Crick (2007) stated that a dynamic individual is one who confirms to get engaged in concerns that touch their society by their transparent participation and belonging in political, economic, religious, and social features of societies.

Definitely, nurturing digital citizens is an indispensable role of schools as students' spirits of respect; commitments, pledges and the responsibility towards community are fostered. Now, language teachers can incorporate international themes in EFL classes which may inspire students to share their concerns online. Earlier in 1974, the UNESCO office declared language teachers' responsibility to inspire citizenship values in language lessons. 
In order to advance digital citizenship, practitioners may benefit from sites such as the International Society for Technology in Education (ISTE). Specifically, implications relevant to digital citizenship were put forth. These implications were relevant to the ability to manage technology skillfully; think and value the truthfulness of content; create, discover, and bond with others as it should be; build inoffensive, responsible, well-mannered choices online (Common Sense Media White Paper , 2011).

The process of interpreting such standards was attempted by many researchers. For example, both Frazer (2002); and Werbner (2000) explained that digital citizenship implies that individuals respect each other regardless of their backgrounds. Through digital citizenship, individuals can display their tolerance, empathy and understanding to each other on the one hand. On the other hand, they can voice their concerns effectively. Similarly, Ribble and Bailey (2007) articulated digital citizenship as entailing nine features of behavior for maintaining citizenship.

Due to such development, technological tools provided EFL learners with interactive tasks for teaching within a communicative approach context. Technological tools provided learners with interactive tasks for teaching language within a communicative approach framework. In this context, writing is an important skill for English language students; for the time being, it is a real concern for the student and the teacher in EFL settings i.e. Kuwait. So, novel methods are needed to increase students' motivation to write. In digital learning environment, numerous reasons affect students' satisfaction. Technology, teacher, and communication were considered crucial in such context (Bollinger \& Martindale, 2004). This combination motivates students towards the learning/teaching process.

In EFL contexts, research decided that student' achievement in writing skills is poor (e.g. Basturkmen \& Lewis, 2002). Now, Kuwaiti schools are supported with Internet that can bring apt backing in learning; yet it seems that technology is not always properly appreciated in language lessons (e.g. Keshta \& Harb, 2013).

In Kuwait, citizenship is fundamental component of curricula. The rudiments of citizenship considered by the Kuwaiti Ministry of Education (2017) are as follows: human rights, peace, democracy, intercultural communication, equity, sustainability, worldwide education and intercultural education. Concerning English language teaching, the Ministry of Education rudiments highlight cognitive demonstration of communicative competence that considers Kuwaiti and international settings.

\section{Statement of the problem}

Nowadays, misapplication of technology is a typical behavioral action in society. Online problems increase crimes related to plagiarism, harassment, etc. (Dashora, 2011). Though the misapplication of technology has many fundamental sources, it would seem sound to propose that the absence of citizenship education is a causative feature (Ribble, Bailey and Ross, 2004). Therefore, the potential effect of technology is addressed by this study. 
There appear to be an agreement among scholars (Alrabai, 2016; Rabab'h, 2003) that EFL students show a rather disappointing level of writing skills. Earlier research credited such unsatisfactory level to a number of causes which vary from the absence of the teaching method or strategy (e.g. Al-Khasawneh, 2010; Alsamdani, 2010; Rabab'ah, 2003). Moreover, one of the researchers, touched students' failure to express themselves successfully all through English language writing classes. Since digital citizenship is a possibly worthwhile in developing students' computer use, technological applications, and language skills, motivation, accordingly, it will be attempted to remedy students' writing performance.

It is true that technology in foreign language classes was investigated only with reference to language skill development; rather from twofold perspective: language and society. This give credits to additional investigations of the effect of some advanced instructional strategies that foster the performance of EFL writers on the one hand, and create 'good' citizens on the other hand simultaneously.

\section{Purpose, question, objectives \& significance}

This research purpose is basically intended to examine the impact of using digital citizenship on refining Kuwaiti EFL students' writing ability. Specifically, the current study seeks to answer the following general question:

-Is there a statistically significant difference between the mean scores of the experimental group taught by the instructional program and the control group taught by the conventional method on the post-test in overall writing performance?

The study's proposed objectives are:

1- To develop students' thinking by encouraging them to generate many ideas relevant to their online writing.

2- To help students activate the pre-writing phase to get clear outlines for their writing tasks.

3- To help students to write a meaningful coherent composition.

4- To provide opportunities for reinforcing students' written language learning.

The present study offers the field of EFL a digital citizenship instructional program where writing is delivered meaningfully. The findings obtained by critically investigating such program are expected to highpoint the significance of citizenship values in EFL curricula, to help textbook writers diminish problems pertinent to topic identification which may in turn empower educational policies for citizenship education. The study is also significant as it nurtures teachers' awareness towards the inclusion of citizenship themes into writing classes which may improve learners' language by having more global themes to write about as the major impetus for carrying out this study can be presented through several aspects that are relevant to the improvement of writing performance. Hence, the integration of technology in teaching the English language in general and teaching writing in particular is expected in the 
time of prompt improvements and changes in the educational system in Kuwait. However, from a theoretical perspective, the significance of this study emerged from the scarcity of addressing this issue in the field of teaching writing by the means of technology, as to the best knowledge of the researchers.

\section{Review of literature}

Digital citizenship has been perceived differently by many authors (viz. traditionally, critically, and conceptually).Traditionally speaking, the term refers to the civil rudiments that comprise one's rights; like: freedom and justice (Banks, 2008). Being a 'good' citizen who has rights (e.g. civil, economic, social,...etc.) and duties (conformity to the law, paying taxes,....etc.) at the same time (Gollob, Krapf \& Weidinger, 2010). In contrast, the critical perspective of digital citizenship highlights the identity of the society as veiling ethnic, cultural or language differences leading to globalized world (Pike, 2000; Subedi, 2010). Nevertheless, the conceptual perspective of digital citizenship is associated with activating citizens as involving discourse and performance (Abu El-Haj, 2007; Dower, 2003).

Writing in English is not only needed for academic study, but it is also an urge for international communication where ideas and feelings are conveyed sensibly (Olango \& Geta, 2016). Of particular focus, writing classes can give students a chance to take part properly in such online platforms due to absence of digital citizenship in any other school subject. Lively interactive writing creates a chance to teach learners, in and outside class, to become accountable citizens. Of course, this may support them to succeed in this web-linked age. This study unconventionally will cover the writing themes encountered virtual platforms. In other words, this study will use technology to teach students share, blog, and comment and discuss in order to be good digital citizens.

Writing is defined as practice of demonstrating ideas and feelings (Nunan, 2003). It is fundamental for worldwide communication as individuals share their opinions, comment, blog and connect with others (Bello, 1997). Writing is very crucial in individual's daily life as well as for the development of other language sub-skills (spelling, acquiring vocabulary, punctuation, conveying ideas and the use of correct grammar) (Liu, 2013; Olango \& Geta, 2016).

Due to its multi- processes and creative nature, writing supports language learning together with enhancing thinking skills. The nature of the writing as a process approach has been discussed by many authors. For example, Krashen (1984) elaborated on the characters of 'good' writers as they plan (brainstorming), rescan (rereading), revise (editing) and recourse (drafting). Similarly, Durst (2006) introduced comparable features; namely: planning (brainstorming), translation (converting ideas into words), and reviewing (evaluation). Referring to writing processes as conventions, Ali and Yunus (2004) highlighted that meaning can be created by: establishing ideas, selecting the proper word that embraces meaning, and having the correct language. To Ferris (2003), content, punctuation, the writer's process, students' ideas, audience, purpose, word choice, spelling, rhetoric organization, mechanics, grammar, and 
syntax features are key in the writing process. In the same vein, Banados (2006) highlighted the processes of writing as entailing different exchanges to be performed by the students steered towards the meaning, structure, mechanism and organization of the message. Nevertheless, improving students' writing involves meaningful-driven instructional approach that considers all such processes.

\section{Empirical studies}

Goldberg, Cook and Russell (2003) studied 99 articles published in 1992-2002 which were relevant to the impact of technology in school students' performance in writing, in USA. Goldeberg et.al carefully chosen 26 articles for the content analysis because not all articles (viz. 25) fit the standards of the analysis. The study reported the effectiveness of using a word processor on the amount and the quality of writing student produce especially for intermediate and high stage students.

Saqqa (2006) investigated the influence of computer-mediated instructional strategies (viz. mind mapping \& brainstorming) on the writing and reading performance of female students at Al-Dur Al-Manthoor Private School for Girls, Jordan. As allocated onto three groups (specifically: 2 expiremental \& one control); 103 tenth grade students took part in the study. For measurement purposes, students' final scores of first semester in English in reading and writing were considered. The study reported significat effectiveness of computer-mediated instruction strategies; especially and foremost in generating ideas as contrasted with the traditional strategy used with control group studnets.

Boyle (2010) investigated the effect of use/misuse of 75 Northeast urban secondary school students who were trained on an adapted digital citizenship program as contrasted with another 75 students from the same school who were not exposed to the program alike. This program was based on Ribble, Bailey \& Ross's (2004) tools of "Digital Driver's License" survey and pre-posttests. Boyle found out statistical significant differences in students' Etiquette, Digital Communication, Digital Literacy, Digital Commerce, Digital Law, Digital Rights and Responsibilities and Digital Health and Wellness categories in favor of students who received training as compared to their peers at the control group.

Darwish and Lakhtaria (2011) explored the potential of Web 2.0 tools enhancing communication behaviors in the Taiwanese and Egyptian revolutions. This technology comprised all social media tools such as wikis, blogs,....etc. Darwish and Lakhtaria highlighted the crucial role of such tools in enhancing communication in these countries.

Ibrahim (2011) examined the impact of computer -based education on increasing university juniors' writing of in Iraq. Data were gathered by the means of preposttest as well as a perception questionnaire. Noticeable improvement was reported in students' writing and communication performance along with positive perceptions towards such digital type of learning. 
Dadour and El-Esery (2014) examined the effect of using a computer software to develop Egyptian students' essay writing. 25 college students took part in the study. To elicit data on students' writing performance, a pre- post test was used. The concluded that using softwares tend to effective to develop students' writing in EFL setting.

Alsaleem (2014) investigated the effect of WhatsApp electronic journaling on 30 EFL undergraduate female students' writing vocabulary in Languages and Translation College, Saudi Arabia. To elicit responses, a pretest-posttest was administered. In the test, participants were asked to send their kind notes on various issues to the members of the WhatsApp group. The outcomes showed an improvement in students' writing performance in word choice and voice foremost.

Alfaki and Alharthy (2014) studied the influence of social networks on developing English language learning. To achieve this purpose, 80 students took part in the study as to follow a quasi-experimental research design. Forty students were selected randomly and placed as experimental; leaving the other 40 in the control one. For data assembly, a pre- and posttests were developed where. Results showed language learning improvement was evident in the experimental group who used social networks traditional instruction.

In Jordan, Bani-Hani, Al-Sobh, and Abu-Melhim (2014) examined the attitudes of 42 university students toward Facebook as an instructional tool for teaching writing. In the study, pre-writing stage was the focal core of the study where ideas are brainstormed. A survey questionnaire was administered to elicit responses.. The study reported statistical significant. Results demonstraed that that groups such as Facebook flourished in their writing performance. Besides, results revealed paricipants' vocabulary learning enhancement when disclosed to other goroups' posts.

Bamanger and Alhassan (2015) studied the influence of podcast lectures in developing 55 scientific section English language writing in King Saud University. In the study, the participants were allocated in two groups; one as experimental and the other as control. To collect data, a writing pre-post test, a rubric and a questionnaire were used. The findings indicated statistical significant improvement relevant to case, spelling and punctuation along with optimistic perceptions towards podcasting-based instruction.

Choi (2016) cultivated a theory-built measurement scale for digital citizenship amid young grownups. To achieve its goal, three stages were followed. In the first phase, digital citizenship concepts were content analyzed; this entailed a content analysis of thirty articles, six papers, four books, and seventeen blogs. In the second phase, validity measures for the items of the scale were insured,. In phase four, eventually, the digital citizenship scale was administered on 508 participants entailing 26-item. The scale included the key elements of digital citizenship as ordered in four groups; namely, ethics, media and information literacy, participation/engagement, and critical resistance. These groups entailed 
eliciting data on: Technical Skills, Local/Global Awareness, Networking Agency, Internet Political Activism, and Critical Perspectives. Choi (p.20), accordingly, established that digital citizenship refers to "abilities, thinking, and action regarding the Internet use, which allows people to understand, navigate, engage in, and transform self, community, society, and the world".

Choo and $\mathrm{Li} \mathrm{Li}$ (2017) investigated the effect of digital tools on essay writing in Malaysia. To achieve the aim of the study, 8 students in teacher education program took part in the study. Students were asked to write journals and interviews. The study reported enhanced writing performance at writing journals as well as interview. Additionally, students were noticed as motivated and more collaborative with peers

In a two phase (quantitative \& qualitative) study, Kara (2018) examined private university students' perceptions and performances of digital citizenship. This mixed method involved eliciting quantitative data by a survey (viz. test) from 435 students. Results showed excessive preference to take part in political debates. Yet, qualitative data (semi-structured interviews) collected from 10 students of the sample showed their reluctance to participate in political debates as they felt such debates troubled them emotionally and made them feel anxious regarding any negative comment that may affect others' future lives.

\section{Methods}

This section is concerned with defining the research design and subjects to be covered. Also, treatment and procedures are explained here.

\section{Participants}

The population of the study consisted of all tenth grade students totaling 40 students in two intact sections enrolled at a Kuwaiti School for Girls. One section was assigned randomly (by putting the names in a basket) as experimental and another as control. Here, social media platforms (viz. EFL Forums, Facebook) app inside and outside the classroom were used in teaching the experimental group. In contrast, the control group received classroom writing instruction without making use of technology. The participants are 14 years old female students who have been studying English as a foreign language since Grade One, at the age of six.

\section{Design}

The current quasi-experimental research entails the following variables. Teaching writing in the language classroom in the traditional way and using social media platforms to teach writing constitute the independent variables. The participants' writing performance is the dependent variable.

\section{Instrument}

At the outset of this empirical study, both the experimental and control groups will sit for a writing performance pretest. The test aims at finding out about the two groups' current level of writing ability. After treatment, the same writing posttest was applied. To obtain valid scores that identify students' writing 
performance, clear criteria to assess their works were identified. To qualify this need, the pre-post writing test assess student' writing in terms of: opinions, magazine articles, letters and writing notes.

Anderson's Rubric (2003: 92) was adopted by the researchers in order to establish students' writing performance in essays. This rubric consisted of six categories: ideas and development, organization, vocabulary, sentence structure, capitalization, in addition to punctuation and spelling. Further, Ribble, Bailey, and Ross's (2004) “Digital Driver's License" perception survey for secondary stage students entailed in the instructional program as covering the domains of: Digital Etiquette, Digital Communication, Digital Literacy, Digital Commerce, Digital Law, Digital Rights and Responsibilities, Digital Health and Wellness.

\section{Procedures}

1. Content analyzing the writing activities and opting digital citizenship elements to be taught in the second semester in the targeted units of ---. If there is no enough activities, instructional material on digital citizenship will be prepared.

2. Identifying the writing activities within which digital citizenship elements are integrated. The activities will be restricted to essay writing only.

3. Constructing the instruments of the study: writing performance test. Then the researchers established the validity and reliability measures of the instruments.

4. Allocating appropriate time for each lesson which depends on the writing stage to be given

5. Conducting a meeting with the participants in the experimental group. In the meeting, the students were given a consent form to be delivered to their parents to provide them with the details about the program. Then, they were familiarized with the chosen technology tools by completing activities on-line that introduced them to each tool. Further, feedback on previous writing knowledge like paragraph development, essay writing, peer review, etc. were delivered.

6. Conducting the pre-test on the control and experimental groups and computing its results in order to enable the researcher to check if the four groups are homogeneous at the beginning for the treatment or not, and to evaluate the students' level in writing.

7. Informing participants about the ethics of the group concerning their language, personal comments or messages, being online present at the time allocated to each class as attendance would be taken.

8. Teaching the experimental group according to Ribble, Baily and Ross's (2004) nine digital citizenship elements in the following manner:

- Defining and explaining each citizenship element,

- Illustrating writing activities for each digital citizenship behavior;

- Providing situations that support the ideas and performances.

- Including websites that enable students to navigate;

- Providing an account of keywords for all elements. 
9. Introducing the students to the targeted learning process approach learning strategies (viz. Mauk, \& Metz (2010): Planning, Organizing, Writing, Editing, Revising and Rewriting) as follows.

a) Planning: the instructor first introduced how the students could brainstorm all their ideas on the given topic. There are several brainstorming techniques but the one used with the participants is the mind mapping/clustering/webbing.

b) Organizing the ideas that they have brainstormed into a coherent structure. Thus, the ideas would be translated in a written organization without paying a lot of attention to structure, word choice, etc. This writing strategy can be used to filter the ideas produced by the students at the previous stage.

c) Write/Writing the first draft of the essay. At this stage, the writer's big concern was to translate the ideas that $\mathrm{s} / \mathrm{he}$ brainstormed and organized into a written form.

d) Edit/ The teacher demonstrated how to apply the language skills knowledge to produce a well-structured piece of writing using the self/peer's editing checklist. At this stage, the writer has to consider the four traits of vocabulary, content and ideas, organization and voice.

10. Administrating a post-test to the control and experimental groups and computing the results where the differences in writing improvement of the two groups of participants are established. At the same time, applying the digital citizenship questionnaire.

\section{The instructional program}

This research purpose is basically intended to examine the impact of using digital citizenship on developing Kuwaiti EFL tenth grade students' writing skills. Writing activities in English Over to You textbook were considered in creating the instructional program. Certainly, the researchers considered the general guidelines of teaching English writing for tenth grade in Kuwait. The pre-tests will help in checking the equivalence between groups regarding their writing performance. Later upon the completion of the training, students' achievement will be assessed by the post-test.

Assorted variety of activities from Over to You textbook on writing were redesigned in order to achieve the outcomes of the program because in the digital citizenship instructional program students joined BRAINPOP EDUCATORS.COM where they may watch videos, play games, have quizzes, choose the correct answers that appeared on the screen. Students can receive feedback and get their scores for their achievement immediately. The prepared program is meant to introduce writing by providing students with a large number of digital citizenship experiences, examples, presenting clear instructional procedures, and monitoring students' writing performance.

Once the content of the instructional program is validated by TEFL specialists and educational technology specialists, it will then applied by the teachers in the school as guided and trained by the researcher through 12 training sessions clarifying the concept of digital citizenship and teaching procedures. Meanwhile, 
the control group will be taught through the method described in the teacher' guide.

\section{Rationale}

Nowadays, misapplication of technology is a typical behavioral action in society. Online problems increase crimes related to plagiarism, harassment, etc. (Dashora, 2011). Though the misapplication of technology has many fundamental sources, it would seem sound to propose that the absence of citizenship education is a causative feature (Ribble, Baily and Ross, 2004). Therefore, the potential effect of technology is addressed by this study. It is true that technology in foreign language classes was investigated only with reference to language skill development; rather from twofold perspective: language and society. This gives credits to additional investigations of the effect of some advanced instructional strategies that foster the performance of EFL writers on the one hand, and create 'good' citizens on the other hand simultaneously.

\section{The Type of the Program}

The instructional program started in November/2018 and ended in December/2018. It is eight weeks within two months, specifically12 training sessions. The researcher redesigned the writing material of units (1-6) of the students' Over to You in order to enhance teachers' use of digital citizenship effectively. Of course, the program was applied only to the assigned experimental group. Here, the students were given two to three sessions for writing during every week assigned for every unit; 45 minutes each.

\section{Objectives of the Program}

The proposed writing instructional program had the following objectives:

1. To write about their opinions on different topics (food, places, etc. ) effectively.

2. To write formal/ informal letters using the suitable language.

3. To write instructions using the suitable language.

4. To fill-in application forms using the suitable language.

5. To define and explain the citizenship elements by:

- Illustrating writing activities for each digital citizenship behavior;

- Providing scenarios that reinforce the concepts and behaviors involved.

- Including some links to websites. These are provided as a place to start a personal own research;

- Providing a list of writing keywords in each of the elements.

\section{Reliability of the Writing Test}

To obtain the reliability of the internal consistency of the test, Kuder-Richardson 20 was used. Reliability of the test was established through giving the test to the same pilot study cohort two weeks after the pretest application according to the test and retest procedures. Pearson correlation co-efficiency between the first and the second application was calculated. The reliability coefficient was found to be 0.95 , which is suitable for the aims of this study. 


\section{Reliability of Scoring}

The participants' writing performance was marked by two experienced EFL teachers, the researcher himself and an English language teacher at the same school. The rubric of the pre and the post- tests was adopted from Anderson (2003) which consists of assessing students' skills in starting ideas, developing topics, organizing sequences of smoothly flowing ideas, using appropriate vocabulary, writing and completing sentences clearly, and showing proficiency in the use of the appropriate mechanics (capitalization, punctunation and spelling). However, for assignments, Over T You (2016) was used. It consists of students demonstrating skills in writing effective topic sentences, effective logic flow of key points, mainly clarity and organization, along with using proper grammar and spelling. The other rater was trained on the scoring rubric prior the correction process.

To establsih inter-rater and upon rating reliability, both raters scored 25 stduents' essays on the pretest. After that, the relaibility cofficient was estimated by using Holstic formula. The inter-rater relaibilty was estimated as 0.88 , which was regarded suitable for the aims of this study.

\section{Results}

To review, the research reads as: -Is there a statistically significant difference between the mean scores of the experimental group exposed to the suggested digital citizenship program and the control group receiving regular instruction on the post-test in overall writing performance in favor of the experimental group? To answer this question, a timed pre-test and a post-test of writing were administrated. The means and standard deviations of the students' scores in the pre-test and the post-test were calculated, along with estimates of mean scores and standard errors of the posttest scores based on the differences between the two levels of instructional delivery, graphic organizers strategies and conventional method, as shown in Table 1.

Table 1: Experimental and Control Groups Writing Performance Pre-test and the Posttest Scores

\begin{tabular}{lcccccccc}
\hline \multicolumn{1}{c}{ Group } & N & Mean & $\begin{array}{c}\text { Std. } \\
\text { Deviation }\end{array}$ & N & \multicolumn{2}{c}{ Post-test } & $\begin{array}{c}\text { Std. } \\
\text { Mean }\end{array}$ & \multicolumn{2}{c}{ Estimate Std. Error } \\
Deans & \\
\hline Experimental & 20 & 13.2 & 4.9 & 20 & 16.9 & 4.86 & 16.5 & 0.37 \\
Control & 20 & 12.3 & 3.1 & 20 & 14.6 & 2.52 & 13.8 & 0.37
\end{tabular}

Table 1 shows the mean scores, standard deviations and the estimated means of the experimental and control groups writing performance in the pre-test and the post-test. Moreover, Crystal clear, the Table states how students in the experimental group outperformed their peers in the control group $(M=16.5$, 13.8, respectively). To ascertain this result further, an ANCOVA was implemented in order to analyze the students' scores, as demonstrated in Table 2. 
Table 2: Experimental Group Post-test ANCOVA

\begin{tabular}{lcccccc}
\hline \multicolumn{1}{c}{ Source } & $\begin{array}{c}\text { Type III Sum of } \\
\text { Squares }\end{array}$ & Df. & $\begin{array}{c}\text { Mean } \\
\text { Square }\end{array}$ & F & Sig. & $\begin{array}{c}\text { Partial Eta } \\
\text { Squared }\end{array}$ \\
\hline Post-test & 466.75 & 1 & 466.75 & 167.34 & 0.00 & 0.81 \\
Group & 73.67 & 1 & 73.67 & 26.41 & 0.00 & 0.41 \\
Error & 103.2 & 37 & 2.789 & & & \\
Corrected Total & 688.95 & 39 & & & &
\end{tabular}

Table 2 shows a statistically significant difference in students' writing performance in the post-test $(\mathrm{F}=26.41, \mathrm{df}=39, \mathrm{P}=0.00)$. In light of these scores, this study reports that the instructional program on focus has significant difference in Kuwaiti tenth grade students' writing performance (at $\alpha \leq 0.05$ ).

\section{Discussion}

Assorted variety of activities from Over to You textbook on writing were redesigned in order to achieve the outcomes of the program because in the digital citizenship instructional program students joined BRAINPOP EDUCATORS.COM where they may watch videos, play games, have quizzes, choose the correct answers that appeared on the screen. Students can receive feedback and get their scores for their achievement immediately. The prepared program is meant to introduce writing by providing students with a large number of digital citizenship experiences, examples, presenting clear instructional procedures, and monitoring students' writing performance. . In this way, the students had the chance to focus on the ideas written down in their own words along with observing connections between ideas.

One possible contributor to the superiority of the experimental group was the sequence of the instructional program which was provided and closely implemented to facilitate learning. During the training, students were constantly asked to be active participants, for example, giving them tasks such as surfing, categorizing information differently following arrangements. When students recorded the questions about a topic in the ' $W$ ' column, they were then asked to share the prior experiences on the topic and list them in the ' $K$ ' column. Here, students were able to identify possible ways to research the needed information and record it in the ' $\mathrm{H}$ ' column. Also, they were able to list new information and knowledge in the ' $L$ ' column. In this concern, Bennett, Wells, and Freelon (2011) demonstrated that entertainment web activities enable learners to comprehend life by the means of games, chatting and commenting, acknowledging prevalent culture. These forms of sharing have the potential of exceeding contrasts between "private and public" (p. 117).

Typically, writing is viewed as an activity that reflects reality enclosed in the classroom. Here, students' writing depicts the surrounding representations of knowledge of such enclosed classroom. In the current study, digital citizenship program expanded the potential of expanding these representations of knowledge and thereby were crystal clear throughout students' post test scores. As a matter of fact, digital technologies delivered by the instructional program did not only enable students to edit, format, save and communicate data, but also it empowered them to search, manipulate, revise, augment, supplement 
their world of knowledge. Of course, this may explain the reason behind their writing skill enhancement.

Similarly, the results of this study are in accordance with the general conclusions drawn from other studies in this regard which claimed digital feeds alters the depiction of knowledge in addition to how knowledge is viewed in writing performance ( Aagaard \& Lund, 2013; Søby, 2013)

Additionally, the digital content used in the experimental group reduced students' miscommunication and ambiguity in written texts as it involved brainstorming represented in charts which were motivational and inspirational for the students to write essays confidently. In fact, most students enjoyed the program, as reported by Basturkmen, Loewen and Ellis (2004) who noted that information is more easily learned and comprehended to write with such when presented digitally. Student's writing in the current study was shaped by the digital program; thus the essays reflected citizen like knowledge.

As noticed by research, digital tools can help in the writing process from the instant of receiving the task up until its delivery. As such, the current study showed dissimilarities between the experimental group and that of the planning process in terms of the digital setting. For example, planning was quicker in the experimental group. Besides, language checkers along with translators were so prevalent in the digital setting. In contrast, these were missing in the control group.

\section{Conclusion}

This study examined the effect of an instructional program on $10^{\text {th }}$ grade students' writing performance. It adds an in-depth description of how digital citizenship program by means of diverse resources explains in writing situations. The digital citizenship program examined in the current study tenth grade students' writing was molded for meaning-making and thereby producing well-structured essays. Specifically, the study concluded the following:

- Kuwaiti students' training modified their writing performance as well as their perception of the elements of citizenship. To the knowledge of the researchers, there has been little research addressed in Kuwait and the Arab countries.

- Findings showed that students were uninformed of the concept "digital citizenship" and its nine elements.

- The training allowed students to write linearly and logically; thereby it enabled them to express their ideas and use the digital instructional program in place of an "instrument for writing."

- The instructional program improved students' writing performance. It increased their interaction, their participation. Thus, the program helped students to overcome their different problems in writing provided them with enjoyable experiences while learning through multiple multimedia environments. 
On the basis of the findings, it is recommended that EFL teachers:

- Focus on including social media platforms along with face to face interaction while teaching language skills.

- $\quad$ Use extra time that they have to prepare multimedia and interactive lessons that include videos, images, electronic tests, YouTube and Power Point as well as having different activities to enhance students' learning.

- Familiarize their students with the digital citizenship elements and help students interact meaningfully.

\section{References}

Aagaard, T., \& Lund, A. (2013). Mind the gap: Divergent objects of assessment in technology-rich learning environments. Nordic Journal of Digital Literacy, 4(8), 225-243.

Abu El-Haj, T. R. (2007). “I was born here, but my home, it's not here": Educating for democratic citizenship in an era of transnational migration and global conflict. Harvard Educational Review, 77 (3), 285-316.

Alfaki, I., \& Alharthy, K. (2014). Towards a digital world: Using social networks to promote learner's language. American International Journal of Contemporary Research, 4(10), 105-114.

Ali, Z., \& Yunus, M. M. (2004). An ESL writing course: Unravelling students' needs and concerns. The English Educator, XXXII, 114-126.

Al-Khasawneh, F. M. S. (2010). Writing for academic purposes: Problems faced by Arab postgraduate students of the college of business, UUM. ESP World., 2(28), 1-23. Retrieved from http://www.esp-world.info/Articles_28/WRITING.pdf

Alrabai, F. (2016). Factors underlying low achievement of Saudi EFL learners. International Journal of English Linguistics, 6(3), 21-37. doi: 10.5539/ijel.v6n3p21

Alsaleem, B. (2014). The effect of "WhatsApp" electronic dialogue journaling on improving writing vocabulary word choice and voice of EFL undergraduate Saudi students. Arab World English Journal, 4(3), 213-225.

Alsamdani, H. A. (2010). The relationship between Saudi EFL students' writing competence, L1 writing-proficiency, and self- regulation. European Journal of Social Sciences, 16(1), 53-63.

Anderson, M. (2015). Technology device ownership. Pew Research Center: Internet and the American Life Project Website. Retrieved from $h t t p: / / w w w . p e w i n t e r n e t . o r g$

Anderson, N. J. (2003). Metacognition in writing: Facilitating writer awareness. In A. Stubbs \& J. Chapman (Eds.), Rhetoric, uncertainty, and the university as text: How students construct the academic experience (pp. 10-30). Regina: Canadian Plains Research Center, University of Regina

Anderson, T., Rourke, L., Garrison, D. R., \& Archer, W. (2001). Assessing teaching presence in a computer conferencing context. Journal of Asynchronous Learning Networks, 5(2), 1-17.

Bamanger, E., \& Alhassan, R. (2015). Exploring podcasting in English as a foreign language learners' writing performance. Journal of Education and Practice, 6(11), 63-74.

Banados, E. (2006). A blended-learning pedagogical model for teaching and learning EFL successfully through an online interactive multimedia environment. CALICO Journal, 23(3), 533-550. 
Bani-Hani, N. A., Al-Sobh, M. A., \& Abu-Melhim, A. R. H. (2014). Utilizing Facebook groups in teaching writing: Jordanian EFL students' perceptions and attitudes. International Journal of English Linguistics, 4(5), 27-34. doi:10.5539/ijel.v4n5p27

Banks, J. A. (2008). Diversity, group identity, and citizenship education in a global age. Educational Researcher, 37 (3) 129-139. doi: 10.3102/0013189X08317501

Basturkmen, H. \& Lewis, M. (2002). Learner perspectives of success in an EAP writing course. Assessing Writing, 8 (1), 31-46.

Basturkmen, H., Loewen, Shawn, \& Ellis, R. (2004). Teachers' stated beliefs about incidental focus on form and their classroom practices. Applied Linguistics, 25(2), 243-272. https://doi.org/10.1093/applin/25.2.243

Bennett, W. L.,Wells, C., \& Freelon, D. (2011). Communicating civic engagement:Contrasting models of citizenship in the youth web sphere. Journal of Communication, 61, 835-856. doi:10.1111/j.1460-2466.2011.01588.x

Bollinger, D., \& Martindale, T. (2004). Key factors for determining student satisfaction in online courses. International Journal of E-Learning, 3(1), 61-67.

Boyle, Clifton J., III (2010). The Effectiveness of a Digital Citizenship Curriculum in an Urban School (Doctoral Dissertation). Johnson \& Wales University. Retrieved from https://eric.ed.gov/?id=ED517315

Brookfield, S. (1995). The getting of wisdom: What critically reflective teaching is and why it's important. National Louis University.

Brown, H. D. (1991). 50 simple things you can do to teach environmental awareness and action in your English language classroom. The Language Teacher 15, 4-5.

Byram, M. (2008). From foreign language education to education for intercultural citizenship: Essays and reflections. Bristol, UK: Multilingual Matters.

Casltes, S., \& Alastair, D. (2000). Citizenship and migration. Routledge, New York, NY, USA.

Choi, M. (2016). A concept analysis of digital citizenship for democratic citizenship education in the internet age. Theory and Research in Social Education, 44(4), 565607. doi: 10.1080/00933104.2016.1210549

Choo, Yee Bee \& Li Li, Kee (2017). Digital writing in English language writing instruction. An International Research Journal of Language and Literature, 28, 1 - 16.

Common Sense Media White Paper (2011). Digital literacy and citizenship in the 21st century: Educating, empowering and protecting America's kids. Retrieved from http://www.commonsensemedia.org/sites/default/files/DigitalLiteracyandCi tizenshipWhitePaper

Crick, B. (2007). Citizenship: The political and the democratic. British Journal of Education. 55 (3), 235-248. doi: 10.1111/j.1467-8527.2007.00377.x

Cummins, J. (1981). Bilingualism and minority language children, Toronto: Ontario Institute for Studies in Education.

Dadour, E., \& El-Esery. A. (2014) Manipulating mind-mapping software to develop essay writing. Research Journal of English Language and Literature (RJELAL), 2(2), 614.

Darwish, Ashraf \& Lakhtaria, Kamaljit (2011). The Impact of the new web 2.0 technologies in communication, development, and revolutions of societies. Journal of Advances in Information Technology, 2(4), 204-216.

Dashora, Kamini (2011). Cyber crime in the society: Problems and preventions . Journal of Alternative Perspectives in the social sciences, 3 (1), 240-259. 
Dower, N. (2003). An introduction to global citizenship. Edinburgh, UK: Edinburgh University Press.

Durst, R. (2006). Writing at the postsecondary level. In P. Smagorinsky (ed.), Research on composition: multiple perspectives on two decades of change. New York: Teachers College Press.

Ferris, D.R. (2003). Response to student writing: Implications for second language students. Mahwah, NJ: Lawrence Erlbaum Associates.

Frazer, E. (2002). Citizenship education: Anti-political culture and political education in Britain. Political Studies. 48(1), 88-103. doi: 10.1111/1467-9248.00252

Goldberg, A., Cook, A., \& Russell, M. (2003). The effect of computers on student writing: A meta-analysis of studies from 1992 to 2002. Journal of Technology, Learning and Assessment, 2(1), 1-9.

Gollob, R., Krapf, P., \& Weidinger, W., (2010). Education for democratic citizenship and human rights in school practice Teaching sequences, concepts, methods and models. Council of Europe.

Ibrahim, T. (2005). Global citizenship education: Mainstreaming the curriculum? Cambridge Journal of Education, 35(2), 177-194. doi: 10.1080/03057640500146823

Ibrahim, W. (2011).The effect of computer-enhanced learning through the use of asynchronous discussion on improving writing and student perception of technology-mediated environment. Quality Educational Journal, 2(21), 726-750.

Kara, N. (2018). Understanding university students' thoughts and practices about digital citizenship: A mixed methods study. Educational Technology \& Society, 21 (1) 172185.

Keshta, A. \& Harb, I. (2013).The effectiveness of a blended learning program on developing Palestinian tenth graders' English writing skills. Education Journal, 2(6), 208-221.

Krashen, S. (1984). Writing: research, theory, and applications. Oxford: Pergamon. doi: $10.1017 /$ S0272263100006197

Liu, Meihua (2013). Blended learning in a university EFL writing course: Description and evaluation. Journal of Language Teaching and Research, 4(2), 301-309. doi:10.4304/jltr.4.2.301-309.

Mauk, John \& Metz, John (2010). The composition of everyday life: A guide to writing. United States: Boston, MA Wadsworth: Cengage .

Medges, P. (1998).The fifth paradox: What's the English lesson all about" in: DASCAL, R. Proceedings of the IATEFL-East Editura Eurobit Timisoara.

Nunan, David (2003). Practical English language teaching. Singapore: MC Grow-Hill.

Olango, M., \& Geta, M. (2016).The impact of blended learning in developing students' writing skills: Hawassa University in focus. African Educational Research Journal, $4(2), 49-68$.

Pike, G. (2000). Global education and national identity: In pursuit of meaning. Theory Into Practice, 39, 64-73. doi: 10.1207/s15430421tip3902_2

Rababa'h, G. (2003). Communication problems facing Arab learners of English. Journal of Language and Learning, 3(1) 180-197.

Rababa'h, G. (2005). Communication problems facing Arab learners of English. Journal of Language and Learning, 3(1) 180-197. 
Ribble, M., \& Bailey, G. (2007). Digital citizenship in schools. International Society for Technology in Education (ISTE), Eugene, OR.

Ribble, Mike S., Bailey, Gerald D., \& Ross, Tweed W.(2004). Digital citizenship: Addressing appropriate technology behavior. Learning $\mathcal{E}$ Leading with Technology, 32 (1), 6-9.

Richardson, Janice \& Milovidov, Elizabeth (2019). Digital citizenship education handbook. Council of Europe.

Ross, A. (2007). Multiple identities and education for active citizenship. British Journal of Education. 55(3), 286-303. doi: 10.1111/j.1467-8527.2007.00380.x

Saqqa, S. (2006). The effect of computer assisted semantic mapping and brainstorming on Jordanian upper basic stage students' reading comprehension and Writing in English (Doctoral dissertation), Jordan: Amman Arab University for Graduate Studies.

Søby, M. (2013). Synergies for better learning - where are we now? Nordic Journal of Digital Literacy, 8(01-02) 3-11.

Subedi, B. (Ed.). (2010). Critical global perspectives: Rethinking knowledge about global societies. Charlotte, NC: Information Age Publishing.

UNESCO (1974) Recommendation concerning education for international understanding, co-operation and peace and education relating to human rights and fundamental. Adopted by the General Conference at its eighteenth session in Paris: UNESCO. Retrieved from https:/ / unesdoc.unesco.org/ark:/48223/pf0000114040.page=144

Werbner, P. (2000). Divided loyalties, empowered citizenship? Muslims in Britain. Citizenship Studies, 4, 2000 (3), 307-324. doi: 10.1080/713658798 


\section{Appendix}

Name: .......... $\quad$ Time:(1:30) $\quad$ Mark.../30

\section{Question one:( 2 marks )}

Complete theses features of expressing an opinion?

When you write your opinion you must give r...............for your views. To get the reader involved you can use the s.............person. You can also ask q........... .If you want people to agree with you, use $p$... Language.

Question two:(4 marks)

Circle the best answer?

1.To start the informal letter we use.

a.Hi!How are you?

b.I write this letter to apply for a job in your hospital.

c.All my friend will come to my party.

d.See you soon.

2.We can end the formal letter with

a.Remember me to all!

b.Lots of happiness and success.

c.Best wishes and good luck.

d.(a),(b) and (c) are right.

3.All the followings are right when we write a magazine articles except....

a.Headline

b.Detailed information

c.Illustration

d. We should use the first person.

4.All the following are right in taking notes except....

a.Use numbers instead of writing in full(1,2,etc. rather than one,two,etc.)

b.Use symbols instead of words $(\&=$ and )

c.Use arrows to connect points.

d.Use full sentences in notes.

Question three (2 marks)

Expand these notes into complete sentences?

1.Text messaging-poor spelling

2.Class presentation-speak clearly

Question four (2 marks)

Put the parts of the personal letter in the correct order?

The signature.........the heading the closing the body 


\section{Question five (20 marks)}

A)Write an essay expressing your opinion about (Saving Water), importance of water, uses of water, water resources and how to save water?(5 marks)

b) Your friend was coming to stay for the weekend but he/she was ill and could not come with you. You had planned a trip. He/she wrote to you ask how the trip went.Write an informal letter?(5 marks) 
c) Write a magazine article about healthy food, what's the healthy food, types of healthy food, quantity of healthy food, importance of health food.(5 marks)

d) Read the following text then try to transform the underlined sentences into suitable notes? ( 5 marks)

A day in Hind's life

Hind is from Jordan. She goes to a school in Amman. She usually packs her school bag in the evening so it is ready in the morning. She gets up at half past six, then she gets washed and dressed. The family has breakfast at seven o'clock. They have tea bread and cheese. She leaves home at quarter past seven .She walks to the bus stop with her brother Ahmad .They get the school bus at half past seven. Her friend Thuraya usually gets the same bus as her and they talk together. School starts at eight o'clock and finishes at one o'clock. In the break, Hind and her friend have a snack. Thuraya sometimes forgets her snack and Hind gives her some of hers. On Wednesday the girls go to the swimming pool.

\section{Good Luck}

